\title{
Strengthening Cultural Confidence and Focusing on the Future
}

\author{
Yafan $\mathrm{Hu}$ \\ Department of Social Sciences \\ Qiqihar Medical University \\ Qiqihar, China 161006
}

\begin{abstract}
Cultural confidence is a high appreciation of a country, a nation and a political party on their own cultural values, and a firm belief in their own cultural vitality. Only had firm confidence in their own culture, could they be firm and calm, have strenuous courage to forge ahead, and have innovative and creative vitality. We should treat our culture and foreign cultures correctly, so that we can fully know the unique advantages of Chinese culture and our development prospects, and further strengthen our cultural beliefs and cultural pursuit. To achieve cultural confidence, the key is to remember one's roots, absorb foreign cultural essence and focus on the future.
\end{abstract}

Keywords—traditional culture; confidence; development

\section{INTRODUCTION}

In the July 1 speech, President Xi Jinping pointed out that we should insist on "four confidences", of which, the confidence in culture was interpreted and especially thought fundamental, widespread and thick. During the course of national rejuvenation, the confidence in culture plays an important role in expression and transfer, and it is a spiritual lead to realize the Chinese dream of grand rejuvenation of Chinese nation.

\section{THE WEAKNESSES OF CURRENT CHINESE CULTURE}

\section{A. Taking about It from the History}

Before the 19th Century, China was the center of the world civilization. Our ancestors had the most powerful culture and the longest civilization, so they were confident in our nation. But in modern times, the Western first entered into the era of industrial civilization, and we lag far behind in science and technology. After 1840, we were always defected in antiinvasion wars, so the cultural confidence of Chinese was smashed step by step. In this period, the Western countries established their confidence. They changed their mentality from extreme inferiority to extreme confidence. Since then, the very asymmetric phenomenon of the Eastern and Western cultures has formed.

\section{B. The Problems in the Reality}

After the founding of the PRC, our information was closed for a time. Our people generally believe that the West was an abyss of suffering, and only China was the paradise of happiness. But with the advent of reform and opening up,
Chinese people see the huge contrast between the richness of the West and the poorness of China at that time, which "wakes up" some people's serious inferiority complex.

\section{The Looting $f$ Western Hostile Forces}

"It is a long-term strategy of foreign hostile forces to contain China's development. To realize this strategy, they need some cards to play. However, the cards of industry, economy, block and embargo they played in past decades were taken away by our country one by one. They begin to play the card of culture. It should be said that they know culture well. Now almost all cultural commanding heights in the world are controlled by the West, such as the Hollywood, Oscar, Europe's three largest international film festivals, Grammy, Nobel, Pulitzer and so on. They attract a lot of talents knowing Chinese culture, and throw a lot of cultural garbage to China. With the generation of Internet, the Western hostile forces think they can affect China's political orientation and cultural orientation in public opinion even without leaving home."

\section{How TO SOLVE THE PROBLEMS}

Attitudes of leaders; how can China's soft power win this cultural war? General Secretary Xi Jinping has talked about the development of Chinese traditional culture and the establishment of cultural confidence separately at students and teachers' forum in Peking University on May 4, 2014, at culture and art work forum on Oct. 15, 2014, at the national propaganda ideology work meeting on Aug. 21, 2013, and at the philosophy and social science work forum in Beijing on May 17, 2016. In his address, Xi Jinping repeatedly referred to the cultural confidence, and pointed out that "to strengthen the confidence on socialist road, theories and system with Chinese characteristics, is to firm cultural confidence. Cultural confidence is the more basic, deeper and more lasting strength."

Task of philosophy workers; at the philosophy and social science work forum, he mentioned cultural confidence, so we can imagine the importance of cultural confidence in the heart of Xi Jinping. How can China's soft power win this cultural war? We need to form a joint force from the academic perspective, to create our own recent history view, solve historical and practical problems and strengthen cultural confidence. Our people shall constantly, unequivocally support 
our Party and our nation from the heart, in our actions and work.

\section{A. To Realize Cultural Confidence Needs Us to Innovate and Develop Our Traditional Culture}

Chinese culture has been deposited for more than a thousand years. It not only is rich in some values and principles but also a lot of unique wisdom.

1) Chinese culture has strong sense: Confucianism, from Confucius (In fact, it started from the coexistence of tribes and agricultural production), has experienced a lot of changes and thought wars. It survives because it has strong reason. In summarizing the previous wisdom, the most important choice of Confucius is to "not to talk about the strange things about gods".

Confucius pointed out that the core of social system construction is "harmony". He advocated civilized coexistence and was against wars, and relying on theory to resolve disputes in the discussion of social system. As for individuals, Confucius stressed "benevolence" and "learning". He advocated establishing a harmonious environment by "benevolence" and improving the understanding by "learning", so as to avoid meaningless contention and participate in the process of reasoning. Wisdom is the result of learning. Faith is the realm of getting along. Braveness is the courage of personal progress. Righteousness is one's practice of public responsibility. Etiquettes are rules that people comply with for reasonable needs. It is the manifestation of thought and wisdom. If we only know "benevolence" and "etiquette" from Confucius or Confucian culture, we only grasp the surface phenomena and don't know its nature and generation reason.

2) Chinese wisdom is extensive and inclusive: China has a relatively independent and unique natural environment in the world, which enables us to absorb fresh power constantly. Speaking from its geography, it is embraced on three sides by green hills and one side by water. The surroundings are mostly barren lands. The Central Plains enjoys the best location. This layout naturally forms central centripetal force. As of its climate, the temperate climate of China is best for human habitation and development. It fully reflects the cycle law of climate and relatively consistent climate environment of the whole land, which has made the tribes easily generate consensus on natural and social awareness, and facilitated their integration and migration. In the integration, their worship of spirits among different tribes was no longer important, and even couldn't exist. It was replaced by the worship of ancestor, culture and wisdom. These are the roots of Chinese culture.

Chinese Mainland is the ultimate station of the extensive and inclusive cultures, so Chinese culture is relatively independent and meanwhile absorbs the essence of other ethnic culture. It attaches importance to entirety, stability, harmony and permanence. It is independent but open, inclusive and elegant. The social changes on Chinese Mainland can be a complete microcosm of the changing world. We can see similarities between disputes of the internal states in ancient China and internal diplomatic disputes. With the above conditions, the generation of "transforming" thought is not surprising. "Transforming", as the start and destination of wisdom, well reflects the philosophy of Chinese culture.

3) Chinese culture is the deepest spiritual pursuit: Chinese culture contains the basic spirit genes of Chinese nation. It represents the unique spiritual identity of Chinese nation. It has not only provided rich cultural resources for the life and growth, and the development of Chinese nation, but also made a unique contribution for the progress of human civilization. It has created a glorious history, and today still shines its lights. Russell once said, "modern world extremely needs some of China's supreme ethical qualities". "If they can be adopted by the world, people on earth will be happy and peaceful now". Nowadays, there is "a craze for Chinese traditional culture" in our country, "a fever of Chinese culture" and "a craze for Confucianism" in many foreign countries. Lots of people are discussing the times value of Chinese traditional culture, such as, kindness, peopleorientation, integrity, righteousness, harmony, great unity and other thoughts, which shows the real meaning of our traditional culture. It is not wise to forget our ancestors, look down upon tradition or smear national culture. Of course, we shouldn't stick to old traditions. But we should carry forward outstanding traditional culture and discard the dross. We should rely on new practice, conform to the trend of the times, and constantly create new cultures. We should absorb the best and discard the dross in the traditional culture. We should make the past serve the present, and get rid of the stale and bring forth the fresh. With scientific combing and careful extraction, we can refine useful ideological values and carry them forward. They will become the inexhaustible source of the national spirit.

4) Marxism has introduced advanced ideological connotation into Chinese culture: Marxism is the greatest achievement in the history of human thought. It reveals the basic law of the development of human society with scientific world outlook and methodology, and points out the right direction for the construction of advanced culture. Our Party has raised this flag since its birth, and constantly propelled Marxism with Chinese characteristics with the combination of the reality of China. It has formed the two great theoretical results of Mao Zedong Thought and the socialist theoretical system with Chinese characteristics, including Deng Xiaoping Theory, the important thought of "Three Represents", Scientific Development Outlook and other major strategic thoughts, which guide Chinese culture forward. Marxism has injected advanced ideological connotation into Chinese culture. Chinese people have access to scientific, sharp ideological weapon, which is a great spiritual and ideological liberation. As Chairman Mao said, "since Chinese people learnt Marxism, our Chinese has transformed from passive resistance into active protection." We cannot forget our "ancestors", because it is the conclusion of history and the inevitable result of reality. In the new situation, we shall adhere to Marxism as a guide, and use ongoing Marxism to 
lead our cultural construction, so that we can distinguish the mainstream and tributaries, the advanced and the backward, the positive and the active in complex social consciousness and cultural environment, effectively lead all kinds of social thoughts, resist the decadent culture influence, and constantly consolidate the common ideological foundation of unity and struggle of the Party and the whole nation.

In the historical practice of revolution, construction and reform, our Party has created a distinctive and uplifting cultural revolution. The precious wealth, including Jinggangshan Spirit, Long March Spirit, Yan'an Spirit, Xibaipo Spirit, Lei Feng Spirit, Daqing Spirit and the spirit of two bombs and one satellite, the spirit of manned spaceflight, Beijing Olympic Spirit, the spirit of earthquake relief, etc. is rich of the characteristics of the times. It realizes the regeneration and reconstruction of Chinese culture, and laid a solid foundation for our cultural construction in the new historical conditions. Currently, some people, in the name of the so-called re-evaluation, advocate the historical nihilism. They thought the revolutionary culture has past and been out of date, and it has no meaning today. They joke the history, remove red classics, and comment historical figures subversively, which is a distortion to history and a desecration to culture. As a Chinese, we should see the hard revolutionary course of Chinese people and the revolutionary culture in the course. It is the essence of our excellent culture and a vivid reflection of the great creative spirit of the Communist Party of China and Chinese people. No matter at present or in the future, the revolutionary culture is a powerful spiritual force that inspires us to make unremitting efforts. To build and develop socialist advanced culture, we should make good use of the abundant revolutionary cultural resources created by the Party and people. We should plant it deeply into people's spiritual world and constantly gather new spiritual forces.

\section{B. Treat Our Traditional Culture with Correct Guiding Ideologies}

We should establish and strengthen the correct cultural mentality and establish the correct guiding ideology to treat traditional Chinese culture.

1) Base on our own country and open to the world: On the one hand, contemporary Chinese culture, based on the historical background of the turn from old century into new century, should have strong spirits of the times. On the other hand, it should deal with the relationship of "domestic culture" and "foreign cultures", namely the relationship of our nation and global integration. It is obviously not wise to completely absorb traditional culture. It is unrealistic to completely reject it. The complete rejection and Westernization of our traditional culture will destroy our country and harm our people, so we should base on nowadays and make the past serve the present. To base on our own country is to develop and construct our culture according to our national conditions, customs and society conditions. We should solve our problems according to our own conditions. To open to the world requires us to have an open attitude in the cultural construction, and not to seclude our country from outside world.

2) Establish a strong national consciousness and patriotism: We need to cherish and treat the spiritual wealth created by ancestors with an admirable attitude, and cultivate and establish a persistent cultural psychological identity. In the period of cultural transformation, we need to rely on traditional culture, and carry out independent thinking and judgment. One of the most appalling consequences of complete Westernization is to spread ethnic inferiority. We should distinguish the right and the wrong, and not take their abandoned bugs as treasure.

3) Get rid of the self-centered mode: In the history, Chinese culture has been in a leading position for a long time due to many factors, such as geographical environment, which made our people generate a strong cultural superiority and a self-centered cultural attitude. We should get rid of this bad arrogance, and clearly know that the "Central State" is a narrow concept of the feudal era, and the global village is the correct positioning. We should face reality and exchange with other ethnics in an equal attitude.

\section{Promote Cultural Exchanges in an Open and Inclusive Attitude.}

How can China promote cultural exchanges with an open and inclusive attitude, help people of all countries know us comprehensively and enhance their friendship with Chinese people?

1) We should promote cultural exchanges with an open and inclusive attitude: General Secretary $\mathrm{Xi}$ Jinping emphasized civilization exchanges and mutual learning. In September 2014 at the opening ceremony of the Fifth General Assembly of the International Symposium and the International Confucian Association in memory of Confucius's 2565 anniversary, General Secretary Xi Jinping pointed out: "civilization will be more colorful with exchanges and richer with mutual learning. Any civilization, no matter which country produces it, or which social soil of nation grows it, is flowing and open. This is an important law of civilization dissemination and development. In the longterm evolution, Chinese civilization gained rich nutrition from the exchange with other civilizations, and made important contributions to the progress of human civilization. The opening of the Silk Road, a large number of missions to Sui and Tang Dynasties, the pilgrimage of Faxian and Xuanzang for Buddhist scriptures, Zheng He's seven travels to the West, etc. are vivid examples of cultural exchange and mutual learning. Confucianism is China's knowledge, but it has long been spread to the world, as part of human civilization." The historical exchanges and mutual learning of Chinese and foreign civilizations reveal that flow and openness are the general law of civilization development.

2) Explore the development mechanism of Chinese traditional culture spirit: General Secretary further pointed out that, "from this continuous 2000 years of history, we can 
see several characteristics. First, Confucianism and other theories in the history of China are opposite but united. They complement and learn from each other. Confucianism long occupied the dominant position, but it has always been in a harmony state with other theories. Second, Confucianism and other theories in the history of China are migrating and changing with the times. They continuously develop and update, and follow Chinese social development and progress of the times, so they have a long life. Third, Confucianism and other theories in the history of China insist on the principle of humanistic pragmatism, pay attention to the function of culture and education, and combine personal and social education with the governance of the country to achieve the mutual supplement and promotion purpose." Obviously, the Confucianism, as the dominant thought, formed a status of one primary and many secondary suppliers with other theories, and a mutual learning mode. They exchange with each other and learn from each other. To an extent, the branches of Confucianism, Buddhism and Taoism flow together, but they keep their own characteristics. They jointly serve to construct the humanistic spirit world of Chinese.

\section{CONCLUSION}

Confident culture is open. Confident culture is innovative and free. Considering the history and the reality, we shall learn lessons from the history, further explore the development mechanism of Chinese traditional cultural spirit, and make people become a staunch supporter of Chinese culture.

\section{REFERENCES}

[1] Wei Zhaolie. Strengthening Revolutionary Cultural Confidence Needs to Solve Three Basic Problems Scientifically. Journal of School of CPC Shijiazhuang Municipal Committee. 2016 (10).

[2] Bai Xuezhu. Analysis of Cultural Leadership and Cultural Confidence. Leadership Science. 2016 (28).

[3] Zhang Yunyi. Setting up the Cultural Confidence Needs Us to Get Rid of Occidentalism. 2016 (10).

[4] Lu Pingting. Contemporary Chinese Cultural Confidence. Journal of Eastern Liaoning University (SOCIAL SCIENCE EDITION). 2016 (05).

[5] Shen Zhuanghai. Value Confidence, the Core of Cultural Confidence. Truth Seeking. 2014 (18).

[6] Zhang Dongmei et al. Cultivation and Protection of Cultural Confidence, the Core Value of Socialist. Theory. 2016 (09).

[7] Peng Jinsong et al. Thinking on Enhancing Cultural Confidence. Theory Perspective. 2016 (09).

[8] Zhang Chunhe. Analysis of Strengthening Value Approach of Cultural Confidence - Education of Socialist Core Values. Theory and Reform. 2016 (06).

[9] Yan Liguang. "Chinese Road" of Rebuilding Cultural Confidence and Spiritual World - Construction of Socialist Core Values. Social Science Journal of Jiamusi University. 2015 (04).

[10] Zhou Juan. Cultivating and Practicing Socialist Core Values in Cultural Confidence. Learning Monthly. 2014 (08). 